\title{
2,6-Dibrominated 3,5-DistyrylBODIPYs as Photosensitizer Dyes for Photodynamic Antimicrobial Chemotherapy
}

\author{
Kelechi A. Lebechi, Bokolombe P. Ngoy, John Mack ${ }^{\circledR}$ and Tebello Nyokong \\ Institute for Nanotechnology Innovation, Department of Chemistry, Rhodes University, 6140 Makhanda, South Africa \\ ${ }^{\circledR}$ Corresponding authorE-mail: j.mack@ru.ac.za
}

This article was submitted to a special issue dedicated to Prof. Dieter Wöhrle's 80 ${ }^{\text {th }}$ Birthday

\begin{abstract}
A 2,6-dibrominated BODIPY core dye with a meso-pyrenyl group has been investigated for use as a photosensitizer dye in photodynamic antimicrobial chemotherapy in the context of both gram-positive (Staphylococcus aureus) and gramnegative (Escherichia coli) bacteria, along with a $\pi$-extended 3,5-di-4-carboxystyrylBODIPY dye. The dyes are found to be effective for the treatment of $S$. aureus, but not in the case of E. coli.
\end{abstract}

Keywords: BODIPY dyes, Knoevenagel condensation, photodynamic antimicrobial chemotherapy, singlet oxygen, photophysics, TD-DFT calculations.

\section{2,6-Аибромированные 3,5-АистирилBODIPY как фотосенсибилизирующие красители Аля фотодинамической антимикробной химиотерапии}

\author{
K. А. Лебечи, Б. П. Нгой, Аж. Мак, ${ }^{@}$ T. Ниоконг \\ Институт инноваций в области нанотехнологии, кафедра химии, Университет Родса, 6140 Макана, ЮАР \\ ${ }^{\circledR}$ E-mail:j.mack@ru.ac.za
}

\begin{abstract}
С изелью использования в качестве фотосенсибилизаторов для фотодинамической антимикробной химиотерапии по отношению как к грамположительным (Staphylococcus aureus), так и грамотрицательным (Escherichia coli) бактериям исследованы 2,6-дибромированный ВОDIPY с мезо-пиренильной группой, а такюе л-расширенный 3,5-ди-4-карбоксистирилВОDIРҮ. Обнаружено, что красители эффективны для уничтожения S. aureus, но не обладают противомикробной активностью по отношению $\kappa$ E. coli.
\end{abstract}

Ключевые слова: BODIPY красители, конденсация Кневенагеля, фотодинамическая антимикробная химиотерапия, синглетный кислород, фотофизика, TD-DFT расчеты.

\section{Introduction}

BODIPY dyes are highly fluorescent dyes that have been the focus of increasing research interest over the last three decades due to their potential utility as laser and fluorescent sensor dyes, in solar cells, photodynamic therapy, supramolecular polymers, and nonlinear optical materials.
${ }^{[1-6]}$ These dyes are favorable for a wide range of applications since they are easily synthesized and can be readily modified structurally, have narrow and intense spectral bands that can lie anywhere in the 500-800 $\mathrm{nm}$ region, and high photostability. ${ }^{[7]}$ The introduction of heavy halogen atoms at the 2,6-positions of the BODIPY core enhances the rate of intersystem crossing resulting in high singlet oxygen 

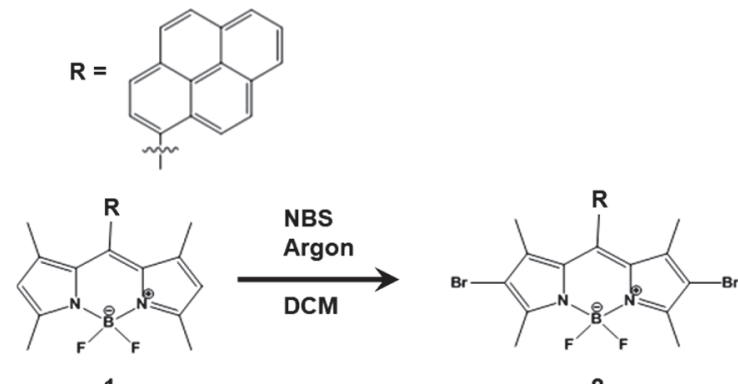

2
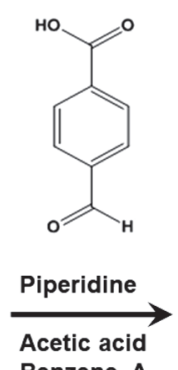

Benzene, $\Delta$

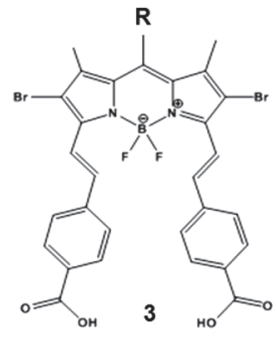

Scheme 1. Synthesis of BODIPYs 2 and $\mathbf{3}$.

quantum yields. ${ }^{[8,9]}$ This makes the dyes potentially suitable for use in singlet oxygen applications such as photodynamic therapy ${ }^{[10-15]}$ and remediation of industrial wastewaters. ${ }^{[16,17]}$ Recently we reported that 2,6-dibrominated dyes exhibit significant antibacterial properties due to their photosensitizer properties. ${ }^{[18]}$ In this study, we investigate the utility of 2,6-dibrominated BODIPY core dyes and $\pi$-extended 3,5-di-carboxystyrylBODIPY dyes (Scheme 1) for photodynamic antimicrobial chemotherapy (PACT) ${ }^{[19-24]}$ by studying their PACT activity on both gram-positive (Staphylococcus aureus) and gram-negative (Escherichia coli) bacteria. Although there have been previous studies on BODIPY core dyes, ${ }^{[25-28]}$ to best of our knowledge, this is the first example of a study of this type with a halogenated 3,5-distyrylBODIPY dye. These dyes are suitable for use with commercially available $630 \mathrm{~nm}$ lasers that are used for photodynamic therapy (PDT), since the main spectral band is red-shifted into the $600-700 \mathrm{~nm}$ region. The introduction of styryl groups at the 3,5-positions also provides scope for enhancing the water solubility of BODIPY dyes by introducing suitable functional groups.

\section{Experimental}

\section{Materials}

Unless otherwise stated, there was no further purification of all reagents prior to use. Trifluoroacetic acid (TFA), 2,4-dimethylpyrrole, 1-pyrenecarboxaldehyde, 4-formylbenzoic acid, benzene, tetrachloro-1,4-benzoquinone ( $p$-chloranil), triethylamine (TEA), boron trifluoride diethyl etherate $\left(\mathrm{BF}_{3} \cdot \mathrm{OEt}_{2}\right)$, $\mathrm{N}$-bromosuccinimide (NBS), anhydrous magnesium sulfate, glacial acetic acid and piperidine, were purchased from SigmaAldrich. Phosphate-buffered saline (PBS) solution ( $\mathrm{pH}$ 6.8) was prepared with appropriate amounts of $\mathrm{Na}_{2} \mathrm{HPO}_{4}$ and $\mathrm{NaOH}$ in ultra-pure water from a Milli-Q Water system (Millipore Corp, Bedford, MA, USA). Nutrient agar and agar bacteriological BBL Muller Hinton broth were purchased from Merck. Escherichia coli (ATCC 25922) was obtained from Microbiologic, and Staphylococcus aureus (ATCC 25923) was purchased from Davies Diagnostics.

\section{Equipment}

UV-Visible absorption spectra were measured at room temperature on a Shimazu UV-2550 spectrophotometer using a $1 \mathrm{~cm}$ pathlength quartz cuvette for solution studies. Fluorescence emission and excitation spectra were obtained using a Varian
Cary Eclipse spectrofluorimeter. Optical densities of the solutions were consistently adjusted to ca. 0.05 . Monochromatic laser light (420-709 nm) from an Ekspla NT 342B-20-AW pulsed laser $(2.0 \mathrm{~mJ} / 5 \mathrm{~ns}, 20 \mathrm{~Hz})$ was used to determine the singlet oxygen quantum yields. Mass spectral data were collected with a Bruker AutoFLEX III Smartbeam TOF/TOF Mass spectrometer. The instrument was operated in positive ion mode using an $\mathrm{m} / \mathrm{z}$ range of 400-3000 amu. The voltages of the ion sources were set at 19 and $16.7 \mathrm{kV}$ for ion sources 1 and 2, respectively, while the lens was set at $8.50 \mathrm{kV}$ and the reflector 1 and 2 voltages were set at 21 and $9.7 \mathrm{kV}$, respectively. $\alpha$-Cyano-4-hydroxycinnamic acid was used as the MALDI matrix with a $337 \mathrm{~nm}$ nitrogen laser selected as the ionising source.

\section{Synthesis}

A previously reported meso-pyrenyl-1,3,5,7-tetramethylBODIPY core dye $\mathbf{1}^{[29]}$ was used as precursor to form the described earlier 2,6-dibrominated dye (2) ${ }^{[29]}$ which in turn was used to form 3,5-di-4-carboxystyryl dye $\mathbf{3}$ through a modified Knoevenagel condensation reaction. ${ }^{[30,31]}$

4,4'-Difluoro(8-pyrenyl)-1,7-dimethyl-2,6-dibromo-3,5-(di4-carboxystyryl)-4-bora-3a,4a-diaza-s-indacene (3). 2 (1 eq), 4-formylbenzoic acid (1.4 eq) and glacial acetic acid $(0.4 \mathrm{~mL})$ were dissolved in dry benzene $(20 \mathrm{~mL})$ under argon with stirring (Scheme 1). Piperidine $(0.4 \mathrm{~mL})$ was added slowly, and the solution was heated to reflux for $2 \mathrm{~h}$ under argon. A Dean-Stark trap was employed for the azeotropic removal of water formed during the condensation reaction. The reaction was quenched with $1 \mathrm{M}$ $\mathrm{HCl}$, and the organic phase was dried over sodium sulfate. The mixture was separated by flash column chromatography with methanol: chloroform (2:3). $\mathrm{m} / \mathrm{z}$ (MALDI-TOF) 870.34; Found: $[\mathrm{M}]^{+}$870.66. UV-Vis (DMSO) $\lambda_{\max }$ (lge) nm: 657 (4.10). ${ }^{1} \mathrm{H}$ NMR ([D6]DMSO, $298 \mathrm{~K}) \delta_{\mathrm{H}} \mathrm{ppm}: 13.02(\mathrm{~s}, 2 \mathrm{H}), 8.67(\mathrm{~s}, 4 \mathrm{H}), 8.38(\mathrm{~s}$, $2 \mathrm{H}), 8.13$ (d, J=8.2 Hz, 2H), 8.05-7.99 (m, 4H), 7.97-7.90 (m, 4H), $7.81(\mathrm{~d}, J=8.0 \mathrm{~Hz}, 2 \mathrm{H}), 7.48-7.52(\mathrm{~m}, 3 \mathrm{H}), 3.25(\mathrm{~s}, 6 \mathrm{H})$.

\section{Antimicrobial Studies}

Staphylococcus aureus and Escherichia coli were grown on agar plates by following the manufacturer's specifications to obtain an individual colony. The colony was inoculated into the nutrient broth and agitated on a rotary shaker ( $c a .200 \mathrm{rpm})$ overnight at $37^{\circ} \mathrm{C}$ (Escherichia coli and Staphylococcus aureus). Aliquots of the culture were transferred to $6 \mathrm{~mL}$ of fresh broth and incubated at $37{ }^{\circ} \mathrm{C}$ to obtain a mid-logarithmic phase (OD $620 \mathrm{~nm} \approx 0.6$ ). The optical densities of the bacteria culture were determined using the Ledetect 96 from Labxim Products so that log reductions could be calculated in colony forming units per millilitre $\left(\mathrm{CFU} \cdot \mathrm{mL}^{-1}\right)$. Through centrifuging for $15 \mathrm{~min}$ at $3000 \mathrm{rpm}$ to remove the broth, the bacterial culture in the logarithmic phase of growth was harvested and washed 
three times in PBS. The bacteria culture was diluted by a factor of $10^{3}$ in PBS to provide a working stock solution. Photodynamic antimicrobial activities of the bacteria were performed following previously reported methods. ${ }^{[32]}$ In all of the experiments, suspensions of the bacteria were incubated in an oven equipped with a shaker for $30 \mathrm{~min}$ in the dark at $37^{\circ} \mathrm{C}$. Then, half $(3 \mathrm{~mL})$ of the incubated bacterial suspensions were irradiated near the absorption band maxima of the photosensitizer dyes in a 24 well plate, using the set-up described above and the other half was kept in the dark. After irradiation, $100 \mu \mathrm{L}$ samples were inoculated and the plates incubated at $37^{\circ} \mathrm{C}$. All the experiments were carried out in triplicate. PACT experiments were conducted by using Thorlabs M660L4 and M530L3 light emitting diodes (LEDs) mounted into the housing of a Modulight 7710-680 medical laser system. Irradiance values of 280 and $110 \mathrm{~mW} \cdot \mathrm{cm}^{-2}$, respectively, were measured in this context with a Coherent FieldmaxII TOP energy/power meter fitted with a Coherent Powermax PM10 sensor.

\section{Photophysical and Photochemical Measurements}

The fluorescence quantum yield $\left(\Phi_{\mathrm{F}}\right)$ is the ratio of the number of photons emitted with respect to the number of absorbed photons. The comparative method was used to determine the fluorescence quantum yield for BODIPY dyes. ${ }^{[33-35]}$ Rhodamine $6 \mathrm{G}\left(\Phi_{\mathrm{F}}=0.95\right.$ in $\left.\mathrm{EtOH}^{[36]}\right)$, and $\mathrm{ZnPc}\left(\Phi_{\mathrm{F}}=0.20\right.$ in $\left.\mathrm{DMSO}^{[37]}\right)$ were used as standards. Excitation of both sample and standard was carried out at their cross-over wavelength, with maximum absorbance kept at ca. 0.05 to avoid inner filter effects. ${ }^{[38]}$ Singlet oxygen is a cytotoxic species that photodegrades/phototransforms organic pollutants as well as initiating apoptosis or cell death during PACT. ${ }^{[16,17]}$ In this regard, quantification of the singlet oxygen quantum yield $\left(\Phi_{\Delta}\right)$ of a compound helps to determine its efficacy for use as a photosensitizer dye. The $\Phi_{\Delta}$ value is defined as the number of singlet oxygen molecules produced for every absorbed photon. The $\Phi_{\Delta}$ value of a photosensitizer can be quantified through a relative method by comparison with a standard with a known $\Phi_{\Delta}$ value. ${ }^{[39,40]}$ A $1 \mathrm{~cm}$ path-length spectrophotometric cell was used for the singlet oxygen quantum yield studies of BODIPY dyes. The rate of singlet oxygen photogeneration was measured in solution in an oxygenated environment with $\mathrm{ZnPc}$, or Rose Bengal used as a reference compound and diphenylisobenzofuran (DPBF) acting as the singlet oxygen scavenger ${ }^{[4]}$ Solutions of the sample and standards containing identical aliquots of DPBF solution were irradiated in the dark. Irradiations were carried out at a wavelength at which absorbance values of the sample and standard solutions are equal, referred to as the cross-over wavelength. The changes in the concentration of DPBF were monitored spectroscopically with each subsequent irradiation. ${ }^{[41]}$ During the study, the initial concentration of DPBF was kept constant in the sample and reference solutions. $\mathrm{ZnPc}\left(\Phi_{\Delta}=0.53\right.$ in $\left.\mathrm{EtOH}^{[42]}\right)$ and Rose Bengal $\left(\Phi_{\Delta}=0.86\right.$ in $\left.\mathrm{EtOH}^{[42,43]}\right)$ were used as standards.

\section{Theoretical Calculations}

The DFT method was used to carry out geometry optimizations in vacuo for BODIPYs 1-3 at the B3LYP/6-31G(d) level of theory by using the Gaussian 09 program package. ${ }^{[44]}$ A similar approach was used to calculate electronic absorption spectra by using the TD-DFT method with the CAM-B3LYP functional, since it includes a long-range correction that incorporates an increasing fraction of Hartree-Fock exchange as the interelectronic separation increases.

\section{Results and Discussion}

The goal of the study is to explore whether 3,5-distyrylBODIPY dyes are suitable for use as photosensitizer dyes in PACT. BODIPY 3 was selected for study, since the mesopyrenyl group is known to enhance the rate of intersystem crossing (ISC) and hence the singlet oxygen quantum yield value. ${ }^{[45]}$ Since it lies orthogonal to the BODIPY core due to steric hindrance with the methyl groups at the 1,7-positions, ${ }^{[7]}$ the bulky meso-group is likely to hinder aggregation. The carboxystyryl groups were incorporated to enhance the solubility in aqueous solution.

\section{Synthesis}

Knoevenagel condensation reactions with aryl aldehydes $^{[30,31]}$ were used to extend the $\pi$-system of BODIPY core dyes 2 through the introduction of 4-carboxystyryl moieties to form compound 3 (Scheme 1) with the goal of enhancing their solubility in aqueous solution. Silica gel chromatography was used to fully separate the 2,6-dibrominated core dye and 3,5-di-4-carboxystyryl BODIPY products (Scheme 1) from the other products of the bromination and styrylation reactions. The ${ }^{1} \mathrm{H}$ NMR spectra can be readily assigned since they are broadly similar to those reported previously for other 3,5-distyryl-, and 3,5-divinyleneBODIPY dyes. ${ }^{[29,46-50]}$ Peaks for the twenty-three aromatic region protons and six methyl protons of 3 can be readily identified in the ${ }^{1} \mathrm{H}$ NMR spectrum, and the parent peak derived by MALDITOF MS was found to be consistent with the anticipated molecular mass. As has been reported previously, ${ }^{[7]}$ halogenation and styrylation result in red shifts of the main BODIPY spectral bands of $\mathbf{2}$ and $\mathbf{3}$, Figure 1 and Table 1.

\section{Theoretical Calculations}

Molecular modelling can be used to analyze the structure-property relationships of BODIPY dyes (Figures 2-4). Although BODIPYs are not aromatic since they lack a macrocyclic ring that obeys Hückel's rule, they still have properties similar to those of aromatic heterocycles due to the rigid indacene plane that is formed upon complexation by boron difluoride. TD-DFT calculations for B3LYP optimized geometries of 1-3 at the CAM-B3LYP/6-31G(d) level of theory predict that the $\mathrm{S}_{0} \rightarrow \mathrm{S}_{1}$ transition is almost

Table 1. Photophysical and photochemical data for BODIPYs 1-3 in DMSO and EtOH.

\begin{tabular}{cccccccc}
\hline & $\begin{array}{c}\lambda_{\text {abs }} \\
(\mathrm{nm})\end{array}$ & $\begin{array}{c}\lambda_{\text {ex }} \\
(\mathrm{nm})\end{array}$ & $\begin{array}{c}\lambda_{\mathrm{em}} \\
(\mathrm{nm})\end{array}$ & $\begin{array}{c}\text { Stokes shift } \\
\left(\mathrm{cm}^{-1}\right)\end{array}$ & $\Phi_{\mathrm{F}}$ & $\Phi_{\Delta}$ \\
\hline DMSO & 506 & 502 & 512 & 389 & 0.14 & - \\
EtOH & 503 & 501 & 507 & 236 & 0.53 & 0.05 \\
\hline & & & $\mathbf{2}$ & & & \\
\hline DMSO & 541 & 538 & 546 & 272 & 0.05 & - \\
EtOH & 533 & 529 & 537 & 282 & 0.05 & 0.91 \\
\hline & & & $\mathbf{3}$ & & & \\
\hline DMSO & 657 & 659 & 669 & 227 & 0.02 & - \\
EtOH & 649 & 651 & 658 & 163 & 0.15 & 0.32 \\
\hline
\end{tabular}




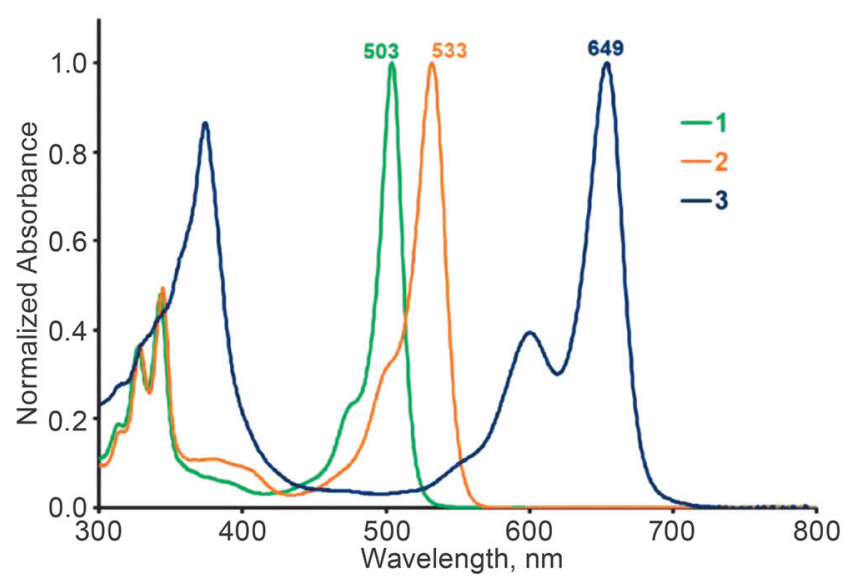

Figure 1. Normalized absorption spectra of BODIPYs 1-3 in ethanol.

completely derived from the HOMO $\rightarrow$ LUMO one-electron transition (Figure 2 and Table 2). When considering the optical properties in the visible region of structurally modified BODIPYs, only the HOMO and LUMO usually need to be considered.

The trends in the main spectral bands of BODIPY core dye 1 (Table 2), its 2,6-dibrominated analogue 2, and the 3,5-di-4-carboxystyryl substituted compound 3 can be readily identified on the basis of the TD-DFT calculations (Figure 2) and the changes in the relative energies of the frontier $\pi$-MOs (Figure 3 ). There is a redshift of about $30 \mathrm{~nm}$ (Figure 1 and Table 1) upon addition of bromine atoms at the 2,6-positions, since the lone pairs of the halogen atoms destabilize the HOMO, which has significant MO coefficients at these positions, through mesomeric interactions in addition to the stabilizing electron

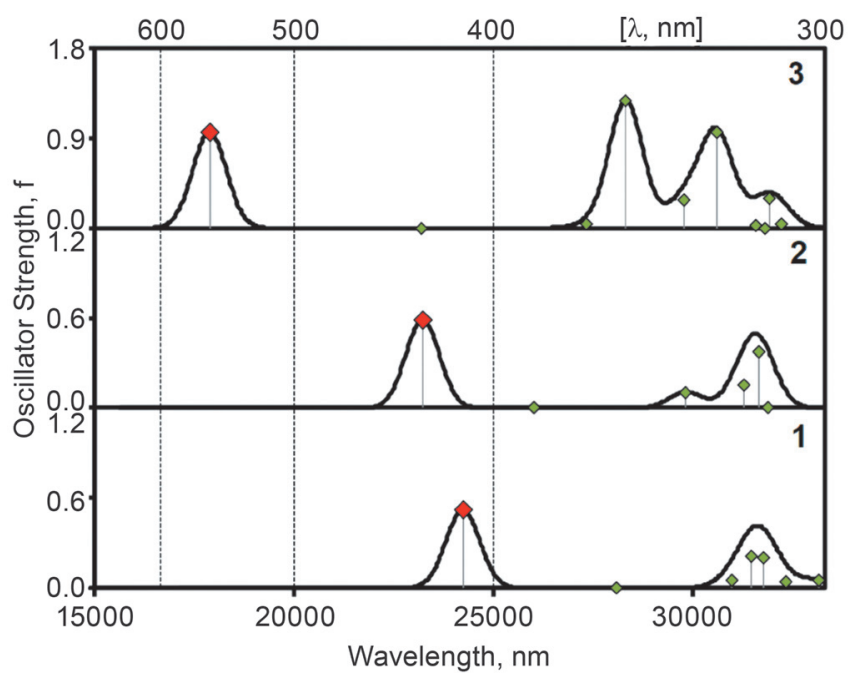

Figure 2. TD-DFT calculations for BODIPYs $\mathbf{1}-\mathbf{3}$ at the CAMB3LYP/6-31G(d) level of theory. Red diamonds are used for the lowest energy spectral bands. The Chemcraft program was used to generate the simulated spectrum with a fixed bandwidth of $1000 \mathrm{~cm}^{-1}$ (Chemcraft - graphical software for visualization of quantum chemistry computations, https://www. chemcraftprog.com). The details of the calculations are provided in Table 2.

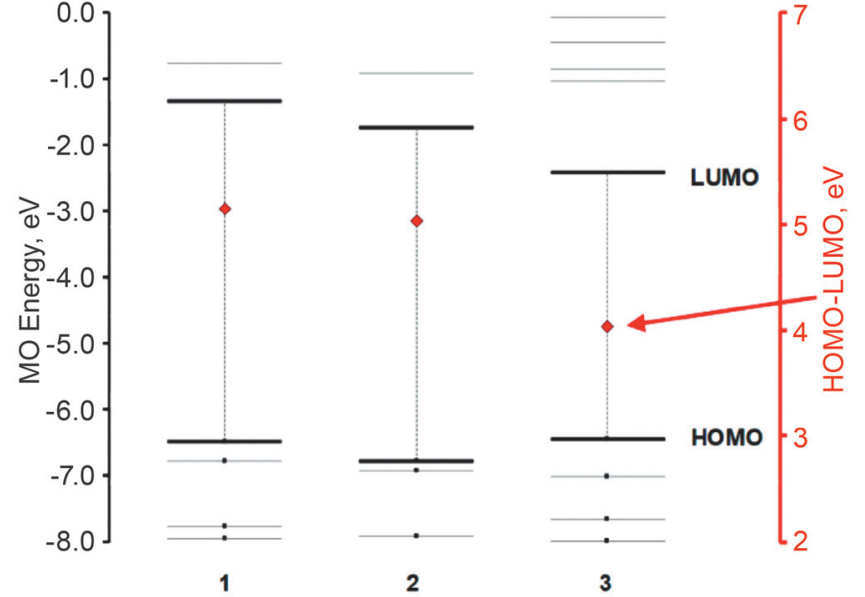

Figure 3. MO energies for BODIPYs $\mathbf{1}-\mathbf{3}$ at the CAM-B3LYP/6$31 \mathrm{G}(\mathrm{d})$ level of theory. Occupied MOs are highlighted with small dark squares. The HOMO-LUMO gap values are denoted with red diamonds and are plotted against a secondary axis.

withdrawing inductive effect of the bromine atoms that affects all the $\pi$-MOs in a similar manner (Figure 4). Hence, there is a narrower HOMO-LUMO band gap and a red-shift of the main spectral band of BODIPY 2 (Figures 1 and 2). The inclusion of the 4-carboxystyryl moieties at the 3,5-positions of 3 results in a further red-shift of $c a .120 \mathrm{~nm}$ (Figure 1, Tables 1 and 2), in a manner similar to what has been reported previously for 3,5-distyrylBODIPYs. ${ }^{[7,9,30,49-51]}$ The larger MO coefficients observed in the HOMO at the 3,5-positions (Figure 4) imply that any structural modifications that introduce an electron donating group and result in a mesomeric effect at this position should affect the HOMO to a greater extent than the LUMO resulting in a change in a significant narrowing of the HOMO-LUMO band gap (Figure 3).

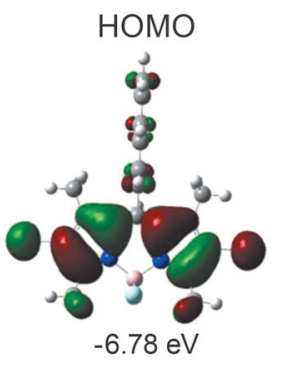

2

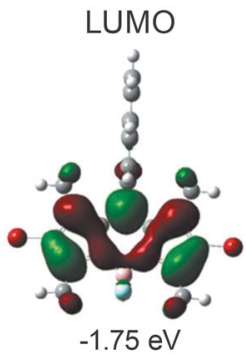

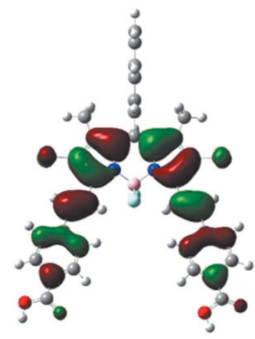

$-6.45 \mathrm{eV}$

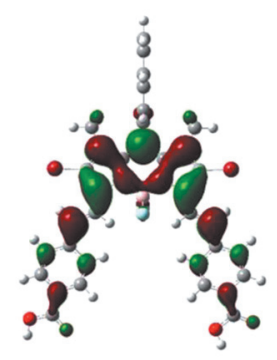

$-2.42 \mathrm{eV}$
Figure 4. Nodal patterns for BODIPYs $\mathbf{2}$ and $\mathbf{3}$ at an isosurface of 0.02 a.u. and a CAM-B3LYP/6-31G(d) level of theory. 
Table 2. TD-DFT calculations at the CAM-B3LYP/6-31G(d) level of theory for the B3LYP optimized geometries of BODIPY 1-3.

\begin{tabular}{cccccc}
\hline & $\mathrm{No}^{\mathrm{a}}$ & $\lambda_{\text {calc }}(\mathrm{nm})^{\mathrm{b}}$ & $\mathrm{f}^{\mathrm{c}}$ & $\lambda_{\text {exp }}(\mathrm{nm})^{\mathrm{b}}$ & Wavefunction $^{\mathrm{e}}=$ \\
\hline $\mathbf{1}$ & 1 & 411 & 0.53 & 503 & $96 \% \mathrm{H} \rightarrow \mathrm{L} ; \ldots$ \\
$\mathbf{2}$ & 1 & 429 & 0.59 & 531 & $92 \% \mathrm{H} \rightarrow \mathrm{L} ; \ldots$ \\
$\mathbf{3}$ & 1 & 567 & 0.94 & 650 & $95 \% \mathrm{H} \rightarrow \mathrm{L} ; \ldots$ \\
& 2 & 384 & 1.09 & - & $93 \% \mathrm{H}-1^{\text {py }} \rightarrow \mathrm{L} ; \ldots$ \\
& 4 & 324 & 0.23 & - & $89 \% \mathrm{H}-6 \rightarrow \mathrm{L} ; \ldots$ \\
& 5 & 310 & 0.63 & - & $75 \% \mathrm{H}-2^{\text {sty }} \rightarrow \mathrm{L}+1^{\text {py }} ; 9 \% \mathrm{H} \rightarrow \mathrm{L}+3^{\text {sty }} ; 7 \% \mathrm{H}-4^{\text {sty }} \rightarrow \mathrm{L}+2^{\text {sty }} ; \ldots$ \\
& 6 & 303 & 0.74 & - & $73 \% \mathrm{H} \rightarrow \mathrm{L}+3^{\text {sty }} ; 8 \% \mathrm{H}-4^{\text {sty }} \rightarrow \mathrm{L} ; 7 \% \mathrm{H}-2^{\text {sty }} \rightarrow \mathrm{L}+1^{\text {py }} ; \ldots$ \\
\hline
\end{tabular}

${ }^{a}$ Excited state number assigned in increasing energy in the TD-DFT calculations.

${ }^{\mathrm{b}} \mathrm{Calculated}$ and experimental wavelengths in $\mathrm{nm}$.

${ }^{\mathrm{c}}$ Calculated oscillator strengths.

${ }^{\mathrm{d}}$ Experimental wavelength in THF (Figure 1).

${ }^{e}$ Wavefunctions of MOs involved in the transition, and their respective contributions, based on eigenvectors predicted by TD-DFT. H and L refer to the HOMO and LUMO, respectively. Superscripts ${ }^{\mathrm{py}}$ and ${ }^{\text {sty }}$ refer to MOs that are localized primarily on the pyrene and styryl moieties, respectively.

\section{Photophysical and Photochemical Properties}

Table 1 provides the main photophysical and photochemical parameters for 1-3 in DMSO and ethanol. BODIPY core dyes usually have high fluorescence quantum yield $\left(\Phi_{\mathrm{F}}\right)$ values due to their rigid planar structures and low ISC rates, but this is known not to be the case when meso-pyrenyl rings are introduced since intramolecular charge transfer states can be formed in polar solvents that result in significant ISC and high significant $\Phi_{\Delta}$ values even in the absence of heavy atoms. ${ }^{[45]}$ The $\Phi_{\mathrm{F}}$ values for 1 in DMSO is 0.14 (Table 1). The introduction of bromine atoms at the 2,6-positions to form 2 results in a relatively high $\Phi_{\Delta}$ value in ethanol of 0.91 by using a comparative method with DPBF as the ${ }^{1} \mathrm{O}_{2}$ scavenger, and a significantly lower $\Phi_{\mathrm{F}}$ value of 0.05 due to the heavy atom effect (Table 1). A moderately high $\Phi_{\Delta}$ value of 0.32 was determined for BODIPY 3 in ethanol. This value is significantly lower than that of $\mathbf{1}$, since the incorporation of styryl groups can be expected to result in significant intramolecular charge transfer character in the $S_{1}$ states, since significantly smaller MO coefficients (Figure 4) are observed on the styryls in the LUMO than in the HOMO. This has been reported to result in enhanced rates of non-radiative decay, especially when polar solvents are used in the context of nonbrominated compounds. ${ }^{[30,52]}$

\section{PACT Studies of Escherichia coli and Staphylococcus aureus in Solution}

PACT is under consideration as an alternative to the use of antibiotics to treat bacterial infections. Studies have shown that bacterial inactivation occurs mainly through outer membrane damage. Typically, neutral anionic or cationic photosensitizer molecules can destroy grampositive bacteria. ${ }^{[33]}$ In the case of gram-negative bacteria, cationic photosensitizers or strategies that can disorganize the gram-negative permeability barrier are required..$^{[53]}$ The difference arises from the cell wall make-up of both kinds of bacteria. Gram-positive bacteria have a cytoplasmic membrane that is surrounded by a relatively porous peptidoglycan layer and lipoteichoic acid that allows the photosensitizer molecules to easily access the inner membranes. ${ }^{[53]}$ In gram-negative bacteria, however, the cell wall consists of an inner and an outer membrane which envelops the peptidoglycan layer, creating an effective permeability barrier between the microorganism and its environment which tends to restrict the penetration of many photosensitizer molecules. ${ }^{[3,54]}$ PACT has been demonstrated to be effective against gram-negative and gram-positive bacteria, yeasts, fungi, protozoa, and viruses, and is advantageous over antibiotics because its use does not lead to the formation of resistant bacterial strains. ${ }^{[55]}$ The development of novel photosensitizer dyes with improved photo-bacterial activities remains an important research goal.

Photodynamic antimicrobial studies were undertaken in $0.2 \%$ DMF solutions because $\mathbf{2}$ and $\mathbf{3}$ were not sufficiently soluble in PBS. In each case, $0.75 \mu \mathrm{g} / \mathrm{mL}$ of the complexes was used. Bacteria such as Staphylococcus aureus are known to be resistant to DMF. ${ }^{[56]}$ The ability of the microbial species to survive was tested in PBS with $0.2 \%$ DMF in the absence of BODIPY dyes as a control experiment (Figure 5). The plots demonstrate that the presence of DMF has a negligible impact on the overall results. Studies were also undertaken to determine if the BODIPY complexes have the capability to inactivate the microorganisms in the dark. Dark toxicity studies (Figure 5) confirm that the BODIPYs $\mathbf{2}$ and $\mathbf{3}$ had no significant dark toxicity even at relatively high concentrations. This indicates that the microbial inactivation was due solely to the production of cytotoxic oxygen species by the BODIPY complexes upon illumination.

BODIPY dyes are relatively small zwitterionic molecules and hence they are potentially favorable for cellular uptake, due to the electron-deficient nature of the BODIPY core. Brominated BODIPY complexes $\mathbf{2}$ and $\mathbf{3}$ were found to be effective when employed as singlet oxygen generating photosensitizers in the photoinactivation of Staphylococcus aureus (Figure 6). BODIPY 3 proved to be the more effective. The log reduction values are relatively high for both 


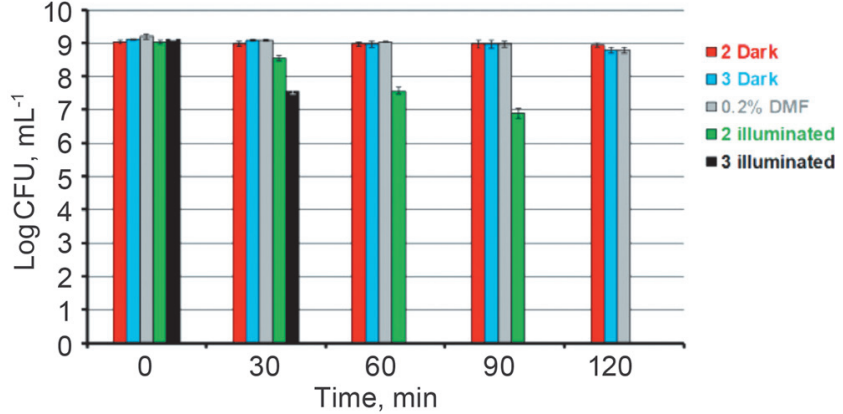

Figure 5. Dark toxicity studies in the presence of Staphylococcus aureus in $0.2 \%$ DMF in PBS for $\mathbf{2}$ and $\mathbf{3}$ with data for $\mathbf{2}$ and 3 illuminated at 30 min intervals with Thorlabs M530L3 and M660L4 LEDs, respectively, provided for comparison.
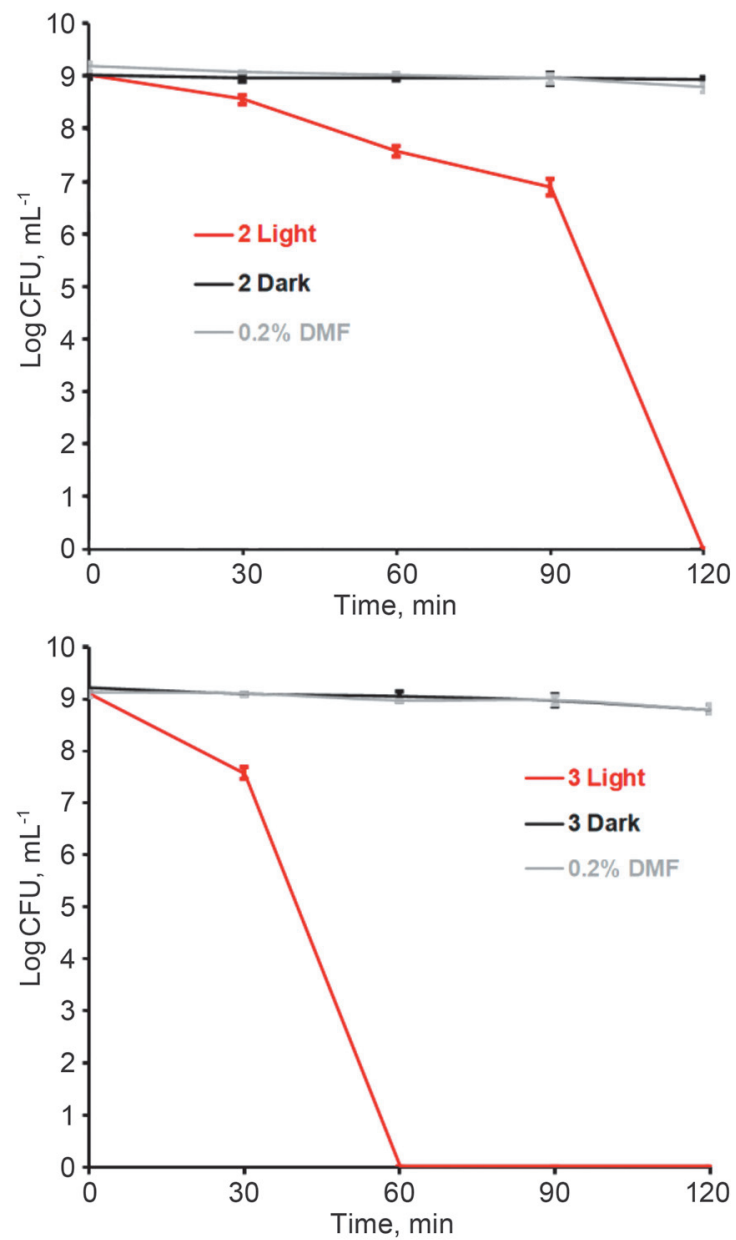

Figure 6. Survival curves of Staphylococcus aureus in PBS (0.2\% DMF) solutions of $\mathbf{2}$ and $\mathbf{3}$. Irradiation of the bacteria was carried out at 30 min intervals with Thorlabs M530L3 and M660L4 LEDs, respectively, to provide a dose of 198 and $504 \mathrm{~J} \cdot \mathrm{cm}^{-2}$ for each 30 min interval.

complexes (Table 3); this can be attributed to the solubility exhibited by the BODIPY complexes in PBS with $0.2 \%$ DMF. Staphylococcus aureus is a gram-positive bacterum with relatively porous cell walls as a result of the peptidogly-

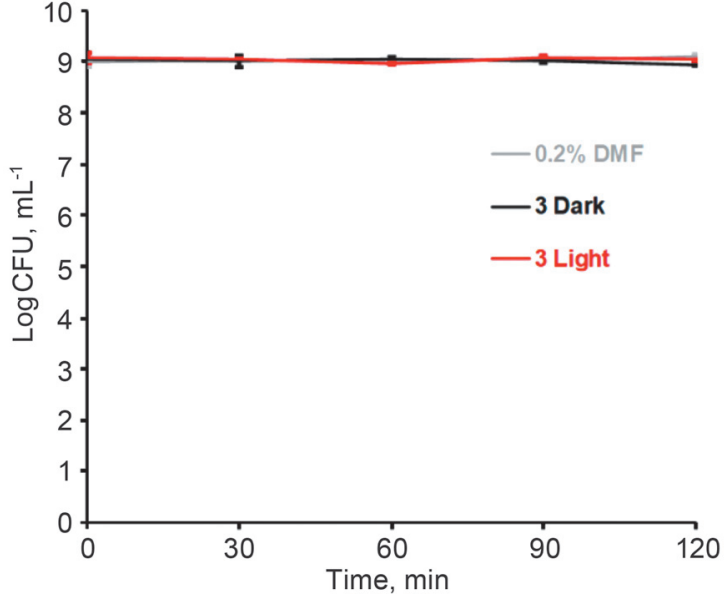

Figure 7. Survival curves of Escherichia coli in a PBS (0.2\% $\mathrm{DMF}$ ) solution of $\mathbf{3}$. Irradiation of the bacteria was carried out at 30 min intervals with a Thorlabs M660L4 LED. This represents a dose of $504 \mathrm{~J} \cdot \mathrm{cm}^{-2}$ for each 30 min interval.

can layer having pore sizes of $9-10 \mathrm{~nm}$ and does not possess an extra polysaccharide layer above the peptidoglycan layer. ${ }^{[57]}$ It has hence been demonstrated that gram-positive bacteria can easily take up photosensitizer dyes and can readily undergo photoinactivation. ${ }^{[56,58]}$

In contrast, Escherichia coli is a gram-negative bacterium which contains an extra outer membrane in the cell wall structure which envelopes the peptidoglycan layer. It is known that the outer membrane is vital to the physiology of gram-negative bacteria such as Escherichia coli, making them resistant to most antimicrobial treatment modalities. ${ }^{[59]}$ The Escherichia coli outer membrane is a layer produced from porin proteins and lipopolysaccharides that can act both as an effective permeation barrier while allowing the efficient diffusion of nutrients. The outer membrane also makes the bacteria outer surface strongly hydrophobic, allowing hydrophobic solutes to cross the outer membrane through the very narrow porin channels. Unlike in Staphylococcus aureus which has larger pores through the peptidoglycan layer and can allow relatively large molecules to pass through, the narrow porin channels in Escherichia coli effectively act as a barrier to the passage of large or hydrophobic compounds. ${ }^{[5]}$

Fluorometric studies have shown that the complexed outermembrane and cell wall of gram-negative bacteria shield the cytoplasmic membrane, hence preventing porphyrinoid molecules from binding to the membrane. ${ }^{[60]}$ In this study, the partial positive charges associated with the electrondeficient electron core are not sufficient to disorganize the gram-negative permeability barrier of Escherichia coli, even when electron-withdrawing carboxylic acid groups are introduced at the para-positions of the styryl groups to enhance the dipole moment generated across the $\pi$-system. The very low log reduction values obtained during the photoinactivation studies on Escherichia coli (Figure 7 and Table 3) can be attributed to this. The dark toxicity studies (Figure 8) demonstrated that BODIPY $\mathbf{3}$ exhibits no dark toxicity in this context. 


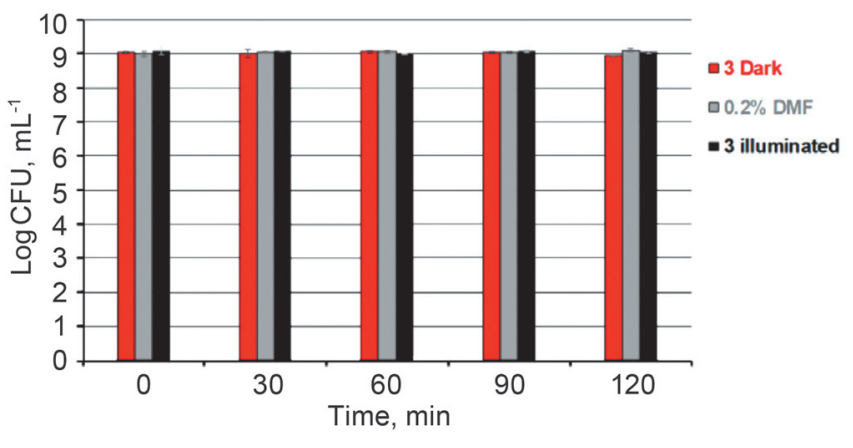

Figure 8. Dark toxicity study in the presence of Escherichia coli in $0.2 \%$ DMF in PBS for 3 with the data for 3 illuminated at $30 \mathrm{~min}$ intervals with a Thorlabs M660L4 LED provided for comparison.

Table 3. Log reduction values for BODIPYs $\mathbf{2}$ and $\mathbf{3}$ after irradiation for 120 min in PBS $(0.2 \%$ DMF $)$ with the standard deviations in brackets.

\begin{tabular}{ccc}
\hline Micro-organism & Dye & Log reduction \\
\hline Staphylococcus aureus & $\mathbf{2}$ & $9.02(0.06)$ \\
& $\mathbf{3}$ & $9.10(0.01)$ \\
\hline Escherichia coli & $\mathbf{3}$ & $0.04(0.05)$ \\
\hline
\end{tabular}

\section{Conclusions}

The PACT activities of novel 3,5-di-4carboxystyrylBODIPY $\mathbf{3}$ and the previously reported meso-pyrenyl 2,6-dibromoBODIPY core dye $\mathbf{2}$ have been investigated. Bacteria studies were undertaken and completed for both Escherichia coli and Staphylococcus aureus. The results obtained were analyzed in terms of $\log$ reductions with BODIPY 3 having a $\log$ reduction value of 9.10 for Staphylococcus aureus. In contrast, the log reduction values for Escherichia coli treated with 3 were very low (Table 3) due to its differing cell wall physiology. The results demonstrate that 3,5-distyrylBODIPY dyes merit further in-depth study for use as photosensitizer dyes in PACT, since they can be readily functionalized on the styryl groups with cationic groups that fully solubilize the dyes in PBS to be suitable for use with both gram-positive and gram-negative bacteria.

Acknowledgements. This work was supported by the Department of Science and Technology (DST) and National Research Foundation (NRF) of South Africa through DST/NRF South African Research Chairs Initiative for Professor of Medicinal Chemistry and Nanotechnology (uid: 62620). Photophysical measurements were made possible by the Laser Rental Pool Programme of the Council for Scientific and Industrial Research (CSIR) of South Africa. Calculations were carried out at the Centre for High Performance Computing in Cape Town.

\section{References}

1. Goze C., Ulrich G., Mallon L.J., Allen B.D., Harriman A., Ziessel R. J. Am. Chem. Soc. 2006, 128, 10231-10239.
2. Buyukcakir O., Bozdemir O.A., Kolemen S., Erbas S., Akkaya E.U. Org. Lett. 2009, 11, 4644-4647.

3. Benniston A.C., Copley G. Phys. Chem. Chem. Phys. 2009, 11, 4124-4131.

4. Kulyk B., Taboukhat S., Akdas-Kilig H., Fillaut J.L., Boughaleb Y., Sahraoui B. RSC Adv. 2016, 6, 84854-84859.

5. Loudet A., Burgess K. Chem. Rev. 2007, 107, 4891-4932.

6. Ndebele N., Hlatshwayo Z., Ngoy B.P., Kubheka G., Mack J., Nyokong T. J. Porphyrins Phthalocyanines 2019, 23, 701-717.

7. Lu H., Mack J., Yang Y., Shen Z. Chem. Soc. Rev. 2014, 43, 4778-4823.

8. Kubheka G., Uddin I., Amuhaya E., Mack J., Nyokong T. J. Porphyrins Phthalocyanines 2016, 20, 1016-1024.

9. Ngoy B.P., Molupe N., Harris J., Fomo G., Mack J., Nyokong T. J. Porphyrins Phthalocyanines 2017, 21, 431-438.

10. Kamkaew A., Lim S.H., Lee H.B., Kiew L.V., Chung L.Y., Burgess K. Chem. Soc. Rev. 2013, 42, 77-88.

11. Yang Y., Guo Q., Chen H., Zhou Z., Guo Z., Shen Z. Chem. Commun. 2013, 49, 3940-3942.

12. Tian J., Ding L., Ju H., Yang Y., Li X., Shen Z., Zhu Z., Yu J.-S., Yang C.J. Angew. Chem. Int. Ed. 2014, 53, 9544-9549.

13. Tian J., Zhou J., Shen Z., Ding L., Yu J.-S., Ju H. Chem. Sci. 2015, 6, 5969-5977.

14. Zou J., Yin Z., Ding K., Tang Q., Li J., Si W., Shao J., Zhang Q., Huang W., Dong X. ACS Appl. Mater. Interfaces 2017, 9, 32475-32481.

15. Gorbe M., Costero A.M., Sancenón F., Martínez-Máñez R., Ballesteros-Cillero R., Ochando L.E., Chulvi K., Gotor R., Gil S. Dyes Pigm. 2019, 160, 198-207.

16. Lebechi A.K., Nyokong T., Mack J. Macroheterocycles 2017, 10, 460-466.

17. Lebechi A.K., Gai L., Shen Z., Nyokong T., Mack J. J. Porphyrins Phthalocyanines 2018, 22, 501-508.

18. Bomanda B.T., Waudo W., Ngoy B.P., Muya J.T., Mpiana P.T., Mbala M., Openda I., Mack J., Nyokong T. Macroheterocycles 2018, 11, 429-437.

19. Wainwright M. J. Antimicrob. Chemother. 1998, 42, 13-28.

20. Liu Y., Qin R., Zaat S.A.J., Breukink E., Heger M. J. Clin. Translat. Res. 2015, 1, 140-167.

21. Wainwright M., Maisch T., Nonell S., Plaetzer K., Almeida A., Tegos G.P., Hamblin M.R. Lancet Infect. Dis. 2017, 17, e49-e55.

22. Kustov A.V., Belykh D.V., Smirnova N.L., Venediktov E.A., Kudayarova T.V., Kruchin S.O., Khudyaeva I.S., Berezin D.B. Dyes Pigm. 2018, 149, 553-559.

23. Hamblin M. Curr. Opin. Microbiol. 2016, 33, 67-73.

24. Maisch T., Eichner A., Spath A., Gollmer A., Konig B., Regensburger J., Baumler W. PLoS One 2014, 9(12), e111792.

25. Caruso E., Banfi S., Barbieri P., Leva B., Orlandi V.T. J. Photochem. Photobiol. B 2012, 114, 44-51.

26. Agazzi M.L., Ballatore M.B., Durantini A.M., Durantini E.N. Eur. J. Med. Chem. 2017, 126, 110-121.

27. Durantini A.M., Heredia D.A., Durantini J.E., Durantini E.N. Eur. J. Med. Chem. 2018, 144, 651-661.

28. Agazzi M.L., Ballatore M.B., Durantini A.M., Durantini E.N., Tomé A.C. J. Photochem. Photobiol. C 2019, 40, 21-48.

29. Kubheka G., Mack J., Kobayashi N., Kimura A., Nyokong T. J. Porphyrins Phthalocyanines 2017, 21, 523-531.

30. Rurack K., Kollmannsberger M., Daub J. Angew. Chem. Int. Ed. 2001, 40, 385-387.

31. Wang S., Liu H., Mack J., Tian J., Zou B., Lu H., Li Z., Jiang J., Shen Z. Chem. Commun. 2015, 51, 13389-13392.

32. Osifeko O.L., Uddin I., Mashazi P.N., Nyokong T. New J. Chem. 2016, 40, 2710-2721.

33. Würth C., Grabolle M., Pauli J., Spieles M., Resch-Genger U. Nature Protocols 2013, 8, 1535. 
34. Brouwer A.M. Pure Appl. Chem. 2011, 83, 2213-2228.

35. Kubin R.F., Fletcher A.N. J. Lumin. 1982, 27, 455-462.

36. Magde D., Wong R., Seybold P.G. Photochem. Photobiol. 2002, 75, 327-334.

37. Ogunsipe A., Nyokong T. J. Porphyrins Phthalocyanines 2005, 9, 121-129.

38. Birch D.J., Imhof R.E. Time-Domain Fluorescence Spectroscopy Using Time-Correlated Single-Photon Counting. In: Topics in Fluorescence Spectroscopy, Vol. 1 (Lakowicz R.E., Ed.) Berlin: Springer, 2002. p. 1-95.

39. Kuznetsova N., Gretsova N., Kalmykova E., Makarova E., Dashkevich S., Negrimovskii V., Kaliya O., Luk'yanets E. Russ. J. Gen. Chem. 2000, 70, 133-140.

40. Waris G., Ahsan H. J. Carcinog. 2006, 5, 14-31.

41. Gandra N., Frank A.T., Le Gendre O., Sawwan N., Aebisher D., Liebman J.F., Houk K., Greer A., Gao R. Tetrahedron 2006, 62, 10771-10776.

42. Redmond R.W., Gamlin J.N. Photochem. Photobiol. 1999, 70, 391-475.

43. Neckers D. J. Photochem. Photobiol. A 1989, 47, 1-29.

44. Frisch M.J., Trucks G.W., Schlegel H.B., et al. Gaussian 09, Revision E.01, Gaussian, Inc., Wallingford CT, 2009.

45. Wang Z., Zhao J. Org. Lett. 2017, 19, 4492-4495.

46. Kubheka G., Sanusi K., Mack J., Nyokong T. Spectrochim. Acta A 2018, 191, 357-364.

47. Harris J., Gai L., Kubheka G., Mack J., Nyokong T., Shen Z. Chem. Eur. J. 2017, 23, 14507-14514.
48. Ngoy B.P., May A.K., Mack J., Nyokong T. J. Mol. Struct. 2019, 1175, 745-753.

49. Ngoy B.P., Hlatshwayo Z., Nwaji N., Fomo G., Mack J., Nyokong T. J. Porphyrins Phthalocyanines 2018, 22, 413-422.

50. May A.K., Stone J., Ngoy B.P., Mack J., Nyokong T., Kimura M., Kobayashi N. J. Porphyrins Phthalocyanines 2017, 21, 832-843.

51. Stone J., Mack J., Nyokong T., Kimura M., Kobayashi N. J. Porphyrins Phthalocyanines 2018, 22, 1-9.

52. Gai L., Mack J., Lu H., Yamada H., Lai G., Li Z., Shen Z. Chem. Eur. J. 2014, 20, 1091-1102.

53. Sharman W.M., Allen C.M., Van Lier J.E. Drug Discov. Today 1999, 4, 507-517.

54. Phoenix D.A., Dennison S.R., Harris F. Photodynamic Antimicrobial Chemotherapy. In: Novel Antimicrobial Agents and Strategies (Phoenix D.A., Dennison S.R., Harris F., Eds) Weinheim, Germany: Wiley-VCH, 2014. p. 295-330.

55. Nishijima S., Namura S., Mitsuya K., Asada Y. J. Dermatol. 1993, 20, 193-197.

56. Ehrenberg B., Malik Z., Nitzan Y. Photochem. Photobiol. 1985, 41, 429-435.

57. Nikaido H. Antimicrob. Agents Chemother. 1989, 33, 1831-1836.

58. Khoza P., Nyokong T. J. Mol. Catal. A 2014, 395, 34-41.

59. Bachmann B.J. Microbiol. Rev. 1990, 54, 130-197.

60. Frenette M., Hatamimoslehabadi M., Bellinger-Buckley S., Laoui S., La J., Bag S., Mallidi S., Hasan T., Bouma B., Yelleswarapu C. J. Am. Chem. Soc. 2014, 136, 15853-15856. 